Tarbawi: Jurnal Ilmu Pendidikan p-ISSN:1858-1080 | e-ISSN: 2615-6547

Vol. 16, No. 1, Juli 2020, 71 - 80

\title{
Self Control Belajar Siswa di Sekolah dalam Menghadapi Era Revolusi Industri 4.0
}

\author{
Dosi Juliawati, Hengki Yandri, dan Nera Afrifadela \\ Institut Agama Islam Negeri Kerinci \\ E-mail: hengki@konselor.org
}

\begin{abstract}
Abstrak. Penelitian ini dilakukan atas dasar masih adanya indikasi siswa yang memiliki self control belajar yang lemah, padahal mereka berada pada era revolusi industri 4,0 yang mengharuskan seseorang memiliki self control belajar yang baik. Jika ini tidak dilakukan tindakan preventif maka akan mengganggu proses belajar siswa di sekolah. Tujuan penelitian ini yaitu untuk mengungkap tingkat self control belajar siswa di sekolah. Penelitian ini menggunakan metode penelitian kuantitatif deskriptif dengan jumlah responden sebanyak 36 orang. Data diungkap menggunakan angket dengan skala self control dan dianalisis menggunakan rumus persentase dan skor ideal. Hasil penelitian ini mengungkapkan bahwa rata-rata tingkat self control belajar siswa di sekolah berada pada kategori cukup baik. Hasil penelitian ini merekomendasikan kepada guru bimbingan dan konseling di sekolah untuk membuat program bimbingan dan konseling dan memberikan layanan bimbingan kelompok dengan tema self control belajar siswa.
\end{abstract}

Kata kunci: Self Control, Belajar, Revolusi Industri 4.0

\begin{abstract}
This research was conducted on the basis of the presence of students who have weak learning self control, even though they are in the era of the industrial revolution 4.0 which requires a person to have good learning self control. If this is not done preventive action it will disrupt the learning process of students at school. The purpose of this study is to reveal the level of self control of student learning in school. This research uses descriptive quantitative research methods with 36 respondents. Data revealed using a questionnaire with a Likert scale and analyzed using the percentage formula and the ideal score. The results of this study reveal that the average level of self control of student learning in schools is in the quite good category. The results of this study recommend to teacher guidance and counseling at school to create guidance and counseling programs and provide counseling group with the theme of self-control learning students.
\end{abstract}

Keywords: Self Control, Learning, Industrial Revolution 4.0 


\section{PENDAHULUAN}

Sekolah merupakan salah wadah bagi peserta didik untuk melatih dan mengembangkan dirinya menjadi manusia yang terampil dalam menghadapi tantangan masa depan dalam menghadapi era revolusi industri 4.0. Sehingga, idealnya sekolah sudah menyediakan media bagi peserta didik dalam menghadapi era revolusi industri 4.0 untuk mengembangkan minat, bakat, kemampuan dan keterampilan yang dibutuhkan oleh dunia industri saat ini. Namun, tidak semua siswa memiliki kesempatan yang sama untuk mengembangkan potensi yang mereka miliki, karena tiap individu memiliki masalah yang kompleks dan tidak pernah sama termasuk peserta didik di sekolah yang sedang memasuki masa remaja. Bagi remaja yang belum memiliki kesiapan yang matang dalam menghadapi permasalahan yang mereka hadapi, mereka akan memiliki kecenderungan salah dalam mengambil keputusan (Nopiarni et al., 2020; Sujadi et al., 2016) karena remaja yang berada pada usia sekolah berada pada masa transisi yang akan banyak mengalami masalah kehidupan yang membutuhkan bimbingan dari orang dewasa (Nopiarni et al., 2020; Santrock, 2003; Yandri \& Juliawati, 2018). Pada masa transisi ini remaja dalam usia sekolah terkadang mengalami tantangan berat dalam mencapai prestasi belajarnya karena terhalang keterampilan belajar yang belum baik (Alfaiz et al., 2019)

Salah satu keterampilan belajar yang perlu dimiliki siswa di sekolah adalah keterampilan dalam mengontrol diri atau self control. Self control merupakan keterampilan seseorang dalam mengarahkan diri atas perilaku dirinya, hal ini bisa terjadi ketika seseorang berusaha mengubah cara mereka berpikir, merasakan, atau berperilaku (Muraven \& Baumeister, 2000). Orang-orang yang memiliki self control yang baik memiliki ciri-ciri sebagai berikut: (1) tekun dan mampu bertahan dengan tugas yang menjadi tanggung jawabnya walaupun ia mengalami banyak rintangan; (2) memiliki kemampuan dalam menyesuaikan diri dengan aturan dan norma yang berlaku dimana saja; (3) perilakunya tidak menunjukkan sikap emosional yang meledak-ledak, dan (4) memilik sifat toleransi yang baik atau mampu menyesuaikan diri dengan baik terhadap situasi yang tidak disenangi (Forzano \& Logue, 1995). Kemudian aspek-aspek kemampuan yang harus dimiliki seseorang agar memiliki self control yang baik yaitu sebagai berikut: (1) kemampuan dalam mengontrol perilaku impulsif; (2) kemampuan mengontrol stimulus; (3) kemampuan dalam mengantisipasi suatu peristiwa atau kejadian, dan (4) kemampuan mengambil Keputusan (Aviyah \& Farid, 2014)

Kemudian, seseorang yang memiliki self control rendah yang tidak mendapat bantuan oleh lingkungan sekitarnya dalam meningkatkan kemampuan self controlnya akan cenderung memiliki perilaku impulsif, lebih suka dengan tugas yang menurutnya sederhana, egois, suka mengambil tindakan berisiko tanpa perhitungan, dan mudah kehilangan kendali emosi karena mudah frustrasi serta akan mudah melakukan kenakalan remaja dan bullying (Aroma \& Sumara, 2012; Santrock, 
2007; Yandri et al., 2013). Kemudian kesimpulan dari data awal hasil wawancara dan observasi yang peneliti kumpulkan menunjukkan adanya indikasi peserta didik memiliki self control yang belum baik, hal ini dilihat dari sikap belajarnya yang masih cuek, suka bergurau dengan teman saat guru sedang memberikan penjelasan, suka ikut-ikutan gaya teman walau terkadang itu menyalahi aturan sekolah seperti berpakaian tidak rapi, cabut dari sekolah dan lain sebagainya. Hal ini juga di dukung oleh penelitian yang di lakukan oleh Sartika dan Yandri (2019) yang mengungkapkan bahwa konformitas teman sebaya memiliki peran penting dalam pengambilan keputusan siswa dalam kelompoknya.

Hal ini menunjukkan bahwa, jika seseorang memiliki self control yang rendah akan mengalami kewalahan dalam mengontrol tingkah lakunya ke arah yang lebih baik. Begitu juga dengan self control dalam belajar, peserta didik yang memiliki self control yang rendah dalam belajar akan mengalami kesulitan dalam meraih prestasi dan pastinya akan mengalami kesulitan dalam belajar, apalagi peserta didik saat ini berada pada era revolusi industri 4.0 yang meminta peserta didik untuk berperan aktif dalam menempa keterampilan dirinya dalam menghadapi dunia industri yang membutuhkan orangorang yang memiliki keterampilan yang dibutuhkan oleh dunia industri. Jika tidak, maka besar kemungkinan peserta didik di masa depannya akan tidak mampu bersaing dengan negara lain. Melihat hal ini, maka peneliti mencoba untuk mengungkap self control belajar siswa di sekolah dalam menghadapi era revolusi industri 4.0 agar menjadi dasar bagi guru mata pelajaran dan guru BK di sekolah dalam mengambil tindakan preventif terhadap tingkah laku peserta didiknya di sekolah terutama self control peserta didik di sekolah.

\section{METODE}

Metode penelitian ini merupakan jenis penelitian kuantitatif dengan menggunakan pendekatan deskriptif yang bertujuan untuk mengungkap tingkat self control belajar siswa di sekolah yang memasuki era revolusi industri 4.0. Populasi dalam penelitian ini yaitu siswa Sekolah Menengah Pertama Negeri 24 Kerinci yang terdiri dari kelas VIII A dan VIII B yang berjumlah 36 orang. Kemudian, pengambilan sampel dalam penelitian ini menggunakan total sampling dengan jumlah sampel 36 orang. Data dalam penelitian ini dikumpulkan dengan menggunakan skala yang digunakan untuk mengukur sikap, pendapat, dan persepsi seseorang atau sekelompok orang tentang fenomena atau gejala alam yang terjadi (Yandri, 2017). Skala self control dalam penelitian ini dikembangkan sendiri oleh peneliti yang telah di uji validitas dan reliabilitasnya.

Data yang sudah diperoleh kemudian dianalisis dengan menggunakan rumus persentase, selanjutnya dilakukan penafsiran terhadap perolehan hasil penelitian yang dilakukan untuk mendeskripsikan data tentang tingkat skor responden mengenai variabel self control belajar siswa di sekolah dengan menggunakan kategori baik, cukup baik, dan tidak baik. Selanjutnya untuk tingkat 
skor responden dihitung menggunakan norma kategorisasi dengan asumsi bahwa skor responden dalam kelompoknya merupakan estimasi terhadap skor individu dalam populasi yang terdistribusi secara normal (Azwar, 2010; Juliawati \& Yandri, 2018)

\section{HASIL}

Temuan penelitian yang telah dilakukan terkait dengan self control belajar siswa dalam menghadapi era revolusi industri 4.0 bisa di lihat pada Tabel 1.

Tabel 1. Self Control Belajar Siswa di Sekolah dalam Menghadapi Era Revolusi Industri 4.0

\begin{tabular}{ccc}
\hline Kategori & Frekuensi & Persentase \\
\hline Baik & 6 & 16.67 \\
Cukup Baik & 17 & 47.22 \\
Tidak Baik & 13 & 36.11 \\
Jumlah & $\mathbf{3 6}$ & $\mathbf{1 0 0}$ \\
\hline
\end{tabular}

Pada Tabel 1 dapat dilihat bahwa dari 36 responden, ada 6 orang responden yang memiliki self control belajar di sekolah dalam menghadapi era revolusi industri 4.0 dengan kategori baik dengan persentase 16,67\%, kemudian ada 17 orang responden berada pada kategori cukup baik dengan persentase $47,22 \%$ dan dan 13 orang responden berada pada kategori tidak baik dengan persentase 36,11\%. Artinya, rata-rata responden sudah memiliki self control belajar di sekolah dalam menghadapi era revolusi industri 4.0, hal ini dibuktikan dengan skor rata-rata perolehan responden yaitu 87,66 atau sebesar 47,22\% yang berada pada kategori cukup baik.

Kemudian, untuk melihat hasil penelitian secara rinci bisa dilihat pada Tabel 2.

Tabel 2. Self Control Belajar Siswa di Sekolah dilihat dari Kemampuan Mengatasi Emosi

\begin{tabular}{ccc}
\hline Kategori & Frekuensi & Persentase \\
\hline Baik & 6 & 16.67 \\
Cukup Baik & 19 & 52.78 \\
Tidak Baik & 11 & 30.56 \\
Jumlah & $\mathbf{3 6}$ & $\mathbf{1 0 0}$ \\
\hline
\end{tabular}

Dari Tabel 2 dapat digambarkan self control belajar di sekolah dilihat dari kemampuan mengatasi emosi. Dari 36 responden, ada 6 orang responden yang berada pada kategori baik dengan persentase 16,67\%, kemudian ada 19 orang responden berada pada kategori cukup baik dengan persentase $52,78 \%$ dan dan 11 orang responden berada pada kategori tidak baik dengan persentase 30,56\%. Hal ini berarti, rata-rata responden sudah memiliki self control belajar di sekolah dilihat dari kemampuan mengatasi emosi, hal ini dibuktikan dengan skor rata-rata perolehan responden yaitu 17,75 atau sebesar 52,78\% yang berada pada kategori cukup baik. 
Tabel 3. Self Control Belajar Siswa di Sekolah dilihat dari Kemampuan Mengatur Perilaku

\begin{tabular}{ccc}
\hline Kategori & Frekuensi & Persentase \\
\hline Baik & 5 & 13.89 \\
Cukup Baik & 14 & 38.89 \\
Tidak Baik & 17 & 47.22 \\
Jumlah & $\mathbf{3 6}$ & $\mathbf{1 0 0}$ \\
\hline
\end{tabular}

Pada Tabel 3, menggambarkan self control belajar siswa di sekolah dilihat dari kemampuan mengatur perilaku. Dari 36 responden, ada 5 orang responden yang berada pada kategori baik dengan persentase $13,89 \%$, kemudian ada 14 orang responden berada pada kategori cukup baik dengan persentase 38,89\% dan dan 17 orang responden berada pada kategori tidak baik dengan persentase $47,22 \%$. Hal ini berarti, rata-rata responden belum memiliki self control dilihat dari kemampuan mengatur perilaku, hal ini dibuktikan dengan skor rata-rata perolehan responden yaitu 18,52 atau sebesar 47,22\% yang berada pada kategori tidak baik

Tabel 4. Self Control Belajar Siswa di Sekolah dilihat dari Kemampuan Mempertimbangkan Keadaan

\begin{tabular}{ccc}
\hline Kategori & Frekuensi & Persentase \\
\hline Baik & 5 & 13.89 \\
Cukup Baik & 17 & 47.22 \\
Tidak Baik & 14 & 38.89 \\
Jumlah & $\mathbf{3 6}$ & $\mathbf{1 0 0}$ \\
\hline
\end{tabular}

Dari Tabel 4 dapat jelaskan tentang self control belajar siswa di sekolah dilihat dari kemampuan mempertimbangkan keadaan. Dari 36 responden, ada 5 orang responden yang berada pada kategori baik dengan persentase $13,89 \%$, kemudian ada 17 orang responden berada pada kategori cukup baik dengan persentase $47,22 \%$ dan dan 14 orang responden berada pada kategori tidak baik dengan persentase $38,89 \%$. Hal ini berarti, rata-rata responden sudah memiliki self control belajar di sekolah dilihat dari kemampuan mempertimbangkan keadaan, hal ini dibuktikan dengan skor rata-rata perolehan responden yaitu 18,22 atau sebesar 47,22\% yang berada pada kategori cukup baik.

Tabel 5. Self Control Belajar Siswa di Sekolah dilihat dari Kemampuan Menafsirkan Situasi

\begin{tabular}{ccc}
\hline Kategori & Frekuensi & Persentase \\
\hline Baik & 6 & 16.67 \\
Cukup Baik & 16 & 44.44 \\
Tidak Baik & 14 & 38.89 \\
Jumlah & $\mathbf{3 6}$ & $\mathbf{1 0 0}$ \\
\hline
\end{tabular}

Pada Tabel 5 dapat jelaskan tentang self control belajar siswa di sekolah dilihat dari kemampuan menafsirkan situasi. Dari 36 responden, ada 6 orang responden yang berada pada kategori baik dengan persentase $16,67 \%$, kemudian ada 16 orang responden berada pada kategori cukup baik dengan persentase 44,44\% dan dan 14 orang responden berada pada kategori tidak baik dengan persentase $38,89 \%$. Hal ini berarti, rata-rata responden sudah memiliki self control belajar 
di sekolah dilihat dari kemampuan menafsirkan situasi, hal ini dibuktikan dengan skor rata-rata perolehan responden yaitu 17,41 atau sebesar 44,44\% yang berada pada kategori cukup baik.

Tabel 6. Self Control Belajar Siswa di Sekolah dilihat dari Kemampuan Mengontrol Keputusan

\begin{tabular}{ccc}
\hline Kategori & Frekuensi & Persentase \\
\hline Baik & 5 & 13.89 \\
Cukup Baik & 20 & 55.56 \\
Tidak Baik & 11 & 30.56 \\
Jumlah & $\mathbf{3 6}$ & $\mathbf{1 0 0}$ \\
\hline
\end{tabular}

Dari Tabel 6 dapat jelaskan tentang self control belajar siswa di sekolah dilihat dari kemampuan mengontrol keputusan. Dari 36 responden, ada 5 orang responden yang berada pada kategori baik dengan persentase 13,89\%, kemudian ada 20 orang responden berada pada kategori cukup baik dengan persentase 55,56\% dan dan 11 orang responden berada pada kategori tidak baik dengan persentase 30,56\%. Hal ini berarti, rata-rata responden sudah memiliki self control belajar di sekolah dilihat dari kemampuan mengontrol keputusan, hal ini dibuktikan dengan skor rata-rata perolehan responden yaitu 15,75 atau sebesar 55,56\% yang berada pada kategori cukup baik.

\section{PEMBAHASAN}

Hasil penelitian yang telah dilakukan mengungkapkan tingkat self control belajar siswa di sekolah dalam menghadapi era revolusi industri 4.0 rata-rata berada pada kategori cukup baik, hal ini dibuktikan dengan skor rata-rata perolehan responden 87,66 dengan persentase 47,22\%. Namun demikian, masih ada sebanyak 36,11\% siswa yang belum memiliki self controldalam belajar yang baik. Seorang yang tidak dapat mengendalikan dirinya di sekolah yang berkaitan dengan kegiatan belajar biasanya mengalami kendala dalam mengontrol perilakunya. Kemampuan seseorang dalam mengontrol perilaku menjadi dasar bagi integrasi pribadi yang dapat mengatur impuls-impuls, pikiran-pikiran, kebiasaan-kebiasaan, emosi-emosi, dan tingkah laku yang berkaitan dengan prinsip-prinsip yang dikenakan pada diri sendiri atau tuntutan yang berlaku di masyarakat (Ulandari \& Juliawati, 2019; Yandri, 2017). Pengendalian diri dari perilaku maladaptif perlu dibangun kesadaran yang kuat dari individu tersebut, agar individu tersebut tidak membuat masalah di masyarakat di mana tempat individu itu berada (Utsman, 2005), hal ini biasanya dilakukan untuk bisa mempertahankan hidupnya dengan baik di masyarakat, pertahanan individu untuk tetap menjadi dirinya sendiri merupakan gejala kepribadian yang tumbuh lebih kuat dalam upaya melindungi maupun menghindarkan diri dari segala sesuatu yang akan merugikan diri sendiri dan menghindarkan diri dari segala sesuatu yang merusak diri. 
Kemudian pembahasan secara rinci indikator-indikator self control belajar siswa di sekolah dikupas dari kemampuan mengatasi emosi berada pada kategori cukup baik dengan rata-rata skor perolehan responden yaitu 17,75 atau sebanyak 52,78\%. Kemudian masih ada sebanyak 30,56\% siswa yang belum memiliki kemampuan dalam mengatasi emosi yang baik. Hal ini menunjukkan bahwa masih banyak siswa yang tidak memiliki kemampuan mengatasi emosi dalam mengendalikan tingkah laku di sekolah, hal tersebut terjadi karena adanya faktor imitasi (peniruan) yang tidak baik dilakukan oleh siswa yang diterapkan di lingkungan sekolah dan siswa terpengaruh dengan siswa lainnya baik di dalam sekolah maupun di luar lingkungan sekolah, seperti yang diungkapkan Manizar (2016) bahwa emosi merupakan salah satu potensi yang dimiliki manusia sejak lahir dan akan berkembang sesuai dengan lingkungannya. Menurut Goleman, orang-orang yang memiliki kecerdasan emosi akan mampu mengenali emosi diri, mengelola emosi, motivasi diri sendiri, mengenali emosi orang lain, dan membina hubungan dengan orang lain dengan baik (Ulandari \& Juliawati, 2019; Yandri, 2017).

Seterusnya self control belajar siswa terkait dengan kemampuan mengatur perilaku di dalam masyarakat berada pada kategori cukup baik dengan rata-rata skor perolehan responden yaitu 18,52 atau sebanyak 38,8\%. Namun, masih ada sebanyak 47,22\% siswa yang belum memiliki kemampuan untuk mengatur perilaku di dalam masyarakat dengan baik. Temuan ini mengindikasikan bahwa masih ada siswa yang belum memiliki akhlak atau karakter yang baik dan belum mematuhi normanorma yang berlaku di sekolah dan di masyarakat. Remaja yang tidak mampu mengontrol perilakunya akan cenderung melakukan tindakan kenakalan remaja, seperti yang diungkapkan oleh Sriyanti (2012) bahwa fenomena kenakalan remaja atau siswa di sekolah, tawuran antar pelajar, tawuran antar kampung, pengeroyokan oleh geng tertentu, pencurian dan perampokan yang disertai kekerasan, perusakan sarana umum dan lain sebagainya merupakan salah satu contoh rendahnya kontrol diri seseorang. Dalam proses belajar, jika siswa memiliki kontrol diri yang tidak baik, maka besar kemungkinan akan terjadi kasus seperti membolos, menyontek, melanggar aturan sekolah, bandel, tidak patuh atau tidak mau mengerjakan tugas-tugas sekolah maupun tugas rumah yang seyogyanya akan merusak diri pribadi siswa tersebut dan bahkan bisa menimbulkan stres akademik (Fatimah et al., 2019) Individu yang kontrol dirinya rendah tidak mampu mengatur dan mengarahkan perilakunya, sehingga diasumsikan seorang pelajar dengan kontrol diri yang rendah akan berperilaku dan bertindak lebih kepada hal-hal yang merugikan dirinya (Angelina, 2013).

Selanjutnya hasil temuan self control belajar siswa terkait dengan kemampuan mempertimbangkan keadaan berada pada kategori cukup baik dengan rata-rata skor perolehan responden yaitu 18,22 atau sebanyak 47,22\%. Namun masih ada sebanyak 38,89\% siswa belum memiliki kemampuan mempertimbangkan keadaan berada dengan baik. adapun faktor penyebab 
perilaku maladatif siswa dalam belajar dan bertingkah laku seenaknya dan kurang peka terhadap aturan dan norma yang berlaku dikaji dari sisi eksternal siswa, bahwa perilaku menyimpang siswa terutama kejahatan ringan seperti mengganggu siswa yang lainnya adalah hasil belajar dari lingkungan atau akibat tekanan dari suatu keadaan tertentu (Aroma \& Sumara, 2012). Individu dengan kontrol diri yang rendah tanpa adanya kemampuan dalam mempertimbangkan suatu keadaan memiliki kecenderungan untuk menjadi impulsif, senang berperilaku berisiko dan berpikiran sempit tanpa berpikir bagaimana keadaan tempat keberadaannya. Hal ini menandakan bahwa remaja belum memiliki keterampilan dalam berpikir positif (Yandri et al., 2019)

Seterusnya temuan peneliti menunjukkan rata-rata tingkat self control siswa dalam belajar terkait dengan kemampuan menafsirkan situasi berada pada kategori cukup baik dengan rata-rata skor perolehan responden yaitu 17,41 atau sebanyak 47,22\%. Namun masih ada sekitar 38,89\% siswa belum memiliki kemampuan menafsirkan situasi dengan baik. Hal tersebut dapat terjadi apabila siswa tidak dapat mencermati situasi yang sedang dihadapinya sehingga siswa tersebut tidak mampu mengendalikan dirinya dalam bertingkah laku. Menurut Fatimah (2017) suatu upaya untuk mengendalikan impuls secara tepat dalam menafsirkan situasi karena kontrol diri juga sangat diperlukan dalam melihat situasi di mana siswa harus berperilaku sesuai dengan situasi yang dihadapi siswa tersebut dalam mengatur dan mengarahkan perilakunya berdasarkan proses kognitif dan psikologis sehingga menghasilkan perilaku yang sesuai dengan yang diharapkan individu tersebut.

Kemudian temuan peneliti menunjukkan rata-rata tingkat self control siswa dalam belajar terkait dengan kemampuan mengontrol keputusan berada pada kategori cukup baik dengan ratarata skor perolehan responden yaitu 15,75 atau sebanyak 61,11\%. Namun masih ada sebanyak 25\% siswa belum memiliki kemampuan mengontrol keputusan dengan baik. Hal tersebut dapat terjadi apabila siswa terburu-buru dalam mengambil keputusan, siswa tidak dapat mengendalikan amarah dan perasaannya. Ketidakmampuan seseorang dalam mengendalikan amarah dan perasaan akan memunculkan sikap negatif yang bisa berujung pada kenakalan remaja, sehingga orang tua dan sehingga guru di sekolah memiliki peran penting dalam membantu siswa agar tidak melakukan penyimpangan berupa kenakalan remaja di sekolah (Juliawati, 2016; Yandri, 2014). Hasil penelitian Wawan (2019) mengungkapkan bahwa salah satu cara yang bisa dimanfaatkan dalam membantu siswa membentuk self control dalam mentaati peraturan sekolah yaitu dengan memberikan poin pada siswa yang melakukan pelanggaran. 


\section{PENUTUP}

Simpulan hasil penelitian ini menunjukkan bahwa secara umum self control belajar siswa berada pada kategori cukup baik. Namun demikian, masih ada beberapa orang siswa yang memiliki self control belajar yang kurang baik seperti pada aspek kemampuan mengatasi emosi negatif, kemampuan mengatur perilaku, kemampuan mempertimbangkan keadaan, kemampuan menafsirkan situasi, dan kemampuan mengontrol keputusan. Dari hasil penelitian ini, direkomendasikan kepada guru bimbingan dan konseling di sekolah untuk membuat program bimbingan dan konseling dan memberikan layanan bimbingan kelompok dengan tema self control belajar siswa.

\section{REFERENSI}

Alfaiz., Yandri, H., Yuzarion, Y., Lestari, L. P. S., \& Heriyani, E. (2019). Persepsi Agentik Individu Untuk Mencapai Prestasi Pribadi dalam Aktivitas Karir: Riset Pendahuluan. Psychocentrum Review, 1(2), 85-95. https://doi.org/10.30998/pcr.1276

Angelina, D. Y. (2013). Pola Asuh Otoriter, Kontrol Diri dan Perilaku Seks Bebas Remaja SMK. Persona:Jurnal Psikologi Indonesia, 2(2), 173-182. https://doi.org/10.30996/persona.v2i2.106

Aroma, I. S., \& Sumara, D. R. (2012). Hubungan antara tingkat kontrol diri dengan kecenderungan perilaku kenakalan remaja. Jurnal Psikologi Pendidikan dan Perkembangan, 01(02)

Aviyah, E., \& Farid, M. (2014). Religiusitas, Kontrol Diri dan Kenakalan Remaja. Persona:Jurnal Psikologi Indonesia, 3(02), 126-129. https://doi.org/10.30996/persona.v3i02.376

Azwar, S. (2010). Penyusunan Skala Psikologi. Yogyakarta: Pustaka Pelajar.

Fatimah, S., Suherman, M. M., \& Rohaeti, E. E (2019). Penerapan Cognitive-Behavioral Therapy dalam Meningkatkan Locus of Control Peserta Didik yang Mengalami Stres Akademik. Jurnal Penelitian Bimbingan Dan Konseling, 4(2), 146-151.

Forzano, L. B., \& Logue, A. W. (1995). Self-Control and Impulsiveness in Children and Adults: Effects of Food Preferences. Journal of the Experimental Analysis of Behavior, 64(1), 33-46. https://doi.org/10.1901/jeab.1995.64-33

Juliawati, D. (2016). Peran Guru Bimbingan dan Konseling/Konselor dalam Mengurangi Tingkat Prokrastinasi Akademik Siswa di Sekolah. Tarbawi: Jurnal Ilmu Pendidikan, 1(2). http://ejournal.iainkerinci.ac.id/index.php/tarbawi/article/view/52

Juliawati, D., \& Yandri, H. (2018). Prokrastinasi Akademik Mahasantri Ma'had Al Jami' ah IAIN Kerinci. Jurnal Fokus Konseling, 4(1), 19-26. https://doi.org/10.26638/jfk.485.2099

Muraven, M., \& Baumeister, R. F. (2000). Self-Regulation and Depletion of Limited Resources: Does Self-Control Resemble a Muscle? Psychological Bulletin, 126(2), 247-259. https://doi.org/10.1037/0033-2909.126.2.247

Nopiarni, R., Yandri, H., \& Juliawati, D. (2020). Perilaku Membolos Siswa Sekolah Menengah Aatas di Era Revolusi Industri 4.0. Bikotetik. (Bimbingan Dan Konseling: Teori Dan Praktik), 03(01), 21-24. https://doi.org/http://dx.doi.org/10.26740/bikotetik.v4n1.p21-24

Santrock, J. W. (2003). Adolescence: Perkembangan Remaja. Jakarta: Erlangga.

Santrock, J. W. (2007). Perkembangan Anak. Jakarta: Erlangga.

Sujadi, E., Yusuf, A. M., \& Marjohan, M. (2016). Hubungan antara Locus Of Control dan Efektivitas Komunikasi antar Pribadi dengan Problem Focused Coping. Konselor, 5(1), 24. https://doi.org/10.24036/02016516490-0-00

Ulandari, Y., \& Juliawati, D. (2019). Pemanfaatan Layanan Bimbingan Kelompok untuk Meningkatkan Kecerdasan Emosi Siswa. Indonesian Journal of Counseling and Development, 1(1), $1-8$. 
Utsman, N. M. (2005). Psikologi Dalam Al-Qur'an (Teori Qur'ani Dalam Penyembuban Gangguan Kejiwaan). Bandung: Pustaka Setia.

Yandri, H. (2014). Peran Guru BK/Konselor Dalam Pencegahan Tindakan Bullying di Sekolah. Jurnal Pelangi, 7(1), 97-107. https://doi.org/10.22202/jp.v7i1.155

Yandri, H. (2017). Efektivitas Dirasah Pengembangan Diri Melalui Pelayanan Konseling dalam Membentuk Kecerdasan Emosi Mahasantri Ma'had Al Jami’ah IAIN Kerinci. Tarbawi: Jurnal Ilmu Pendidikan, 13(01), 1-10. http://ejournal.iainkerinci.ac.id/index.php/tarbawi/article/view/175

Yandri, H., Daharnis., \& Nirwana, H. (2013). Pengembangan Modul Bimbingan dan Konseling untuk Pencegahan Bullying di Sekolah. Konselor, 2(1), 98-106. https://doi.org/10.24036/0201321866-0-00

Yandri, H., \& Juliawati, D. (2018). Profile of the Problem of the Adolescent with Parents as Indonesian Migrant Workers. Konselor, 7(4), 160. https://doi.org/10.24036/0201874101452$0-00$

Yandri, H., Alfaiz., \& Juliawati, D. (2019). Pengembangan Keterampilan Berpikir Positif melalui Layanan Konseling Kelompok bagi Anggota Ikatan Mahasiswa Pemuda Pelajar Semurup, Kota Padang. Jurnal Pengabdian Pada Masyarakat, 4(4), 509-516. https://doi.org/10.30653/002.201944.235 